\title{
La huella de Proust en la obra de Yorgos Seferis
}

Léna Charcharé (Lena Jarjaré) ${ }^{*}$

Traducción: Francisco Salaris

\section{Resumen}

Si confiamos en Seferis cuando afirma que no hay partenogénesis en el arte y que cada uno de nosotros está hecho de todo lo que ha asimilado, entonces podemos llegar con seguridad a la conclusión de que, en este crisol que constituye la composición artística de Yorgos Seferis, la influencia proustiana ha jugado uno de los papeles más significativos. Y esto puede no ser tan obvio en su producción poética como en su única novela, Seis noches en la Acrópolis.

El presente estudio aspira a hacer exactamente eso: señalar meticulosamente las fuentes de inspiración que Seferis encontró en la obra de Marcel Proust. Aparte de las afinidades más evidentes que atañen a la trama y la tematología, también existen muchas más imperceptibles, como la función soteriológica de la literatura o la obsesión ubicua del pasado, entre otras.

Palabras clave: cratilismo, recreador, espejo, mayéutica, espermático, nekyia, mitificación

\section{The imprint of Proust on the work of George Seferis}

\begin{abstract}
If we trust Seferis when he claims that there is no parthenogenesis in art and that each of us is made of all that we have assimilated, then we can safely reach the conclusion that, in this melting pot which constitutes the artistic makeup of Yorgos Seferis, the Proustian influence has played one of the most significant roles. And this may not be as obvious in his poetic production as it is in his unique novel, Six Nights on the Acropolis.

The present study aspires to do exactly that: painstakingly pinpoint the Seferian sources of inspiration in the work of Marcel Proust. Apart from the most obvious affinities which concern the plot and the thematology, there are also many more imperceptible ones, such as the soteriological function of literature or the ubiquitous obsession of the past, among others.
\end{abstract}

Keywords: cratylism, recreator, mirror, maieutica, spermatic, nekyia, mythification

\footnotetext{
Doctora en Literatura y Civilización Francesa, Universidad París-Sorbona III, París, Francia, 1_harhare@hotmail.com 
"Cada uno comienza como puede" (1992a, p. 21) ${ }^{1}$, dice Seferis en el primer volumen de sus Ensayos, refiriéndose a la primera obra de su poeta preferido, T. S. Eliot, a quien tradujo idealmente al griego. Estas cinco palabras resumen lo esencial del bagaje artístico de cada poeta o autor que comienza a escribir una vez que registró y asimiló todo lo leído y vivido antes del momento cosmogónico de su primera frase escrita. Sin embargo, según las propias palabras de Seferis, "no creo que haya partenogénesis en el arte. Cada hombre está hecho de las cosas que asimiló" (1992b, p. 19). Tomando esto como punto de partida, se podrán descubrir más fácilmente las premisas literarias de nuestro poeta, que Yorgos Theotokás compara con tres capas geológicas diferentes:

La primera, la capa más profunda, es la casa familiar, la demótica, la tradición literaria de la lengua viva. Se trata, además, de los maestros antiguos del helenismo de Turquía, que hablan un griego antiguo aún muy robusto ...

La segunda capa es Francia, la totalidad de su enseñanza, que tiene como figura de proa a Racine, su poesía moderna de Baudelaire a Valéry, las corrientes literarias de los primeros años después de la guerra, todo visto desde la perspectiva de París.

La tercera capa es T. S. Eliot, así como todas las experimentaciones poéticas anglosajones de la modernidad. (Theotokás, 2005, pp. 233-252).

Como fuente de inspiración, Proust ocupa un lugar privilegiado en la evolución literaria de Seferis. Comparte con el poeta un cierto número de preocupaciones artísticas que se recuperan en su obra muchas veces no solo como punto de referencia, sino también como prototipo. En su novela Seis noches en la Acrópolis, la única que escribió, llega incluso al límite del plagio — según Denis Kohler (1985, p. 139) —, en cuanto a la descripción de ciertas escenas o en lo que concierne a la composición narrativa. Tomando dicha novela como el epicentro de nuestra atención, intentaremos localizar los puntos de contacto entre Proust y Seferis; el recorrido comenzará con las afinidades narrativas más sobresalientes y acabará en los principios de la vocación artística y en la cuestión del tiempo.

Yorgos Seferis es el nombre de pluma de Yorgos Seferiadis, laureado con el Premio Nobel de Literatura en 1963. Nació el 13 de marzo de 1900 en Urla, una ciudad costera de la provincia de Esmirna (antes Smyrne, hoy Izmir). Su familia tuvo que dejar su hogar en 1914, al comienzo de la Primera Guerra Mundial, pero esos pocos años que vivió sobre las orillas de la antigua Jonia marcaron profundamente su vida y su poesía.

Para los habitantes de la madre Grecia, los griegos de Asia Menor no eran más que migrantes: es por eso que el poeta solía decir que no era griego, sino helénico, poniendo así de relieve su pertenencia idiosincrática no solo al pequeño país balcánico, a la encrucijada entre Europa y Anatolia, sino también al inmenso espacio espiritual del gran helenismo, en su continuidad ininterrumpida de más de veinticinco siglos.

De 1918 a 1924, Seferis y su familia se instalan en París, donde su padre trabaja como abogado. Este quiere que su hijo estudie derecho en la Universidad Panthéon-Sorbonne, pero 
el poeta se inclina más hacia la literatura. Frecuentar asiduamente la vida intelectual francesa alimenta su francofilia; desde entonces, su profunda admiración por los escritores franceses no dejará de profundizarse.

Los años vividos en París son sin duda de los más felices y fecundos de su vida: "Viví seis años y medio en París, ricos años a los que me entregué con toda mi alma, amando cada instante, cada lugar, cada piedra" (Seferis, 1988, p. 113). Lee la Nouvelle Revue Française, frecuenta el Vieux-Colombier y el Théâtre-Français y descubre los grandes autores y poetas franceses (Kohler, 1989, pp. 42-47). Un poco antes de la Navidad de 1931, compra en una librería londinense el pequeño librito del poema Marina, la obra de T. S. Eliot. El descubrimiento capital de la poesía de Eliot sobrepasa la influencia: es el encuentro de un poeta con su hermano de elección (Kohler, 1989, pp. 103-126). Desde entonces, Seferis encuentra el camino de su ser y compone varios poemas mayores.

El acercamiento a Marcel Proust debió de haberse producido durante sus años de formación en París. Seferis sentía un gran respeto por la obra de Proust, el libro del Tiempo, como lo llamaba. Su admiración llega al punto de que incluye frases proustianas en sus poemas: "Longtemps je me suis couché de bonne heure", así comienza su poema en griego "Piazza San Nicolò" (Seferis, 1994, p. 159). Esta admiración muestra, por un lado, su exaltación ante la obra monumental de Proust y su significación; por el otro, se trata sin dudas del asombro de un creador de poemas cortos y concisos ante el autor de una novela gigantesca, compuesta por frases extraordinariamente largas con arabescos hechos de subordinadas, acumuladas o intercaladas hasta el infinito. Este deslumbramiento, quizás, o incluso sus ansias de escribir él mismo pastiches, lo condujeron a la concepción de una obra novelesca. Así nació Seis noches en la Acrópolis. Según sus propias palabras, que se encuentran en el prefacio de su novela, la redacción comienza efectivamente en 1926, año de estadía en París:

En enero (1954), cuando ordenaba unos antiguos papeles, encontré un sobre que contenía escritos de los años 1926-1928. Se trataba de fragmentos de un relato bastante avanzado, de una 'novela', como la llamaba entonces. Eso me dio la idea, temeraria, de juntarlos y de fundirlos para volverlos legibles. Es así que me lancé al presente trabajo, que no destino a la publicación. Me esforcé por permanecer escrupulosamente fiel a esos papeles, y por excluir ideas y sentimientos que habrían podido ser inspirados por personajes o eventos posteriores a 1930. La acción se desarrolla en los años 25-27 ... Inútil precisar que todos los personajes son criaturas imaginarias. (Seferis, 2013, p. 9).

¿Hay que confiar realmente en el poeta cuando dice que todos los personajes son por completo ficticios?, ¿o que no están inspirados de ninguna manera en otros personajes novelescos? Podemos dudar. Comencemos con el personaje central, Stratis, que quiere ser escritor. Es un joven que ama leer, que llena sus escritos con citas de Guillaume Apollinaire, de Platón, de Pascal, de Voltaire y de muchos otros. Ama también los aforismos y se interesa por el arte en todas sus manifestaciones. Tiene un affaire erótico con una mujer casada, Salomé. Atormentado por el carácter esencialmente físico e incumplido de este amor, se enamora de una amiga de Salomé, la bella Lala. Mientras tanto, es testigo de una escena lésbica entre las dos mujeres: las espía, oculto tras un árbol, por una ventana abierta Roderick Beaton lo atribuye a un esfuerzo de adaptación explícita de la escena de Montjouvain de la Recherche (Beaton, 2001, p. 163) y Denis Kohler lo considera un plagio 
patente (1985, p. 139)—. Salomé parece preparar a Stratis para convertirse en el amante de Lala - al final de la novela, Salomé muere y Stratis consuma su affaire con Lala.

Aparte de las relaciones amorosas de los personajes, hay otros elementos de la intriga que están estrechamente ligados a la Recherche: las visitas de Stratis y de sus amigos a un burdel, sus encuentros en salones que recuerdan manifiestamente al pequeño núcleo de los Verdurin, las visitas culturales, la omnipresencia del arte y la búsqueda de un sentido profundo de los actos de los personajes.

En lo que concierne al léxico de la obra, hay un juego de palabras que remite directamente a Proust: "una muchacha en llanto entre las algas" (Seferis, 2013, p. 74), así como alusiones evidentes a la Recherche: "-¡Mira! Veo que tú también tienes la Recherche, dijo ella con una voz sin timbre. Intenté traducirla, pero me asqueó, ¡qué decadencia! -Me gustaría mucho leer lo que hiciste, dijo Stratis" (Seferis, 2013, p. 189). O incluso una cita de Du côté de chez Swann: "Se esforzaba al máximo por encontrar en lo más recóndito de su verdadera naturaleza moral el lenguaje apropiado para la muchacha viciosa que deseaba ser" (Seferis, 2013, p. 157).

Si nos distanciáramos ahora de las similitudes indiscutibles de la superficie e intentáramos profundizar en la poética de la novela, encontraríamos numerosas relaciones que prueban la idiosincrasia identitaria de Proust y de Seferis. La poética de Proust, por un lado, al menos la del período de la inocencia, abunda en ejemplos de una tendencia cratiliana. El cratilismo es una teoría naturalista del lenguaje según la cual los nombres tienen un vínculo directo con su significado. El término proviene del Crátilo de Platón. En este diálogo, Sócrates afirma: "Por consiguiente, Hermógenes, no es cosa de cualquier hombre el imponer nombres, sino de un «nominador». Y éste es, según parece, el legislador, el cual, desde luego, es entre los hombres el más escaso de los artesanos" (Platón, 1992, p. 374). En consecuencia, la teoría del naturalismo se encuentra en las antípodas del convencionalismo que se funda sobre la concepción que el sujeto tiene de la palabra, y sobre el esfuerzo de producir una representación lingüística (verbal y escrita) por medio de una ley que él impone como tal. Para el cratilismo, el centro de interés no es ya el sujeto, sino la cosa. Examinamos la naturaleza del objeto que queremos nombrar y buscamos la denominación más cercana. Además, según este procedimiento, llegamos a una transposición perfecta en todas las lenguas, lo que sería imposible para el creador de nombres [onomatothète] convencional.

El concepto irrumpe en la Recherche por medio de la ensoñación de las palabras y de las etimologías que marcan la época de inocencia del autor. Es la época que determina la parte de la Recherche considerada de aprendizaje, a saber, de Swann a Sodome et Gomorrhe. A decir verdad, los cuatro primeros volúmenes abundan en ejemplos de especulaciones lingüísticas tan imaginativas y de color tan vibrante que no parece verosímil que invadan el relato de manera simplemente fortuita: traducen en realidad la relación del Narrador con el mundo que lo rodea y su nivel emocional con respecto a la verdad de los seres.

El caudal etimológico de Brichot, que deja su huella pedante en el universo apocalíptico de Sodome et Gomorrhe, pone también fin a una suerte de galanteo lingüístico que conduce al Narrador desde su universo infantil e inocente hacia el descubrimiento de verdades más conmovedoras. El esfuerzo de relacionar este preciosismo de la expresión con una concepción filosófica menor de la época platónica no podría ser aleatorio: certifica la estructura intrínsecamente filosófica de la obra, así como la necesidad del autor de dirigir su compás literario hacia los principios más elementales del hombre. Desde entonces, Proust, como Platón, intentará primero conocer la verdad de los seres comenzando por su modo de expresión más revelador: su lenguaje.

El fracaso de la experiencia lingüística cratiliana abrirá otros senderos mucho más sinuosos, pero también más compatibles con la esencia verdadera del ser. El Narrador se dará 
cuenta de que es sobre todo la veta relativista la que caracteriza al hombre, esa tendencia de inconsistencia y de versatilidad que ilumina sus instintos más bestiales.

Pero el cratilismo juega un rol mucho más significativo aún en lo que atañe a la creación y a la vocación artística. Para Proust, la materialización de una ilustración de la realidad completamente iconoclasta necesita de una mirada original, de los ojos de un creador que forje un "universo nuevo y perecedero que ... durará hasta la próxima catástrofe geológica que desencadenará un nuevo pintor o un nuevo escritor originales" (Proust, 2005, p. 336); "univers nouveau et périssable qui ... durera jusqu'à la prochaine catastrophe géologique que déchaîneront un nouveau peintre ou un nouvel écrivain originaux" (Proust, 1987-1989, II, CG, p. 623). Un creador semejante inventa de manera centrífuga una plétora de obras pioneras, ya sea fundadas en una obra existente, como la Berma - "Así la interpretación de la Berma era, en torno a la obra, una segunda obra, vivificada también por el genio" (Proust, 2005, p. 50); “Telle l'interprétation de la Berma était autour de l'œuvre, une seconde œuvre vivifiée aussi par le génie" (Proust, 1987-1989, II, CG, p. 348)—, o inspiradas por la realidad. Los parámetros de una obra de tal calibre sobrepasan largamente los confines de la creación convencional para alcanzar las alturas de una reinvención completa del mundo, o, más precisamente, de nuestra manera de ver el mundo. Proust cree que el hombre literario de valor auténtico debe ser, antes que nada, un recreador, un intérprete subjetivo de su propio modo de concebir el mundo. Debe ser aquel que mostrará a los hombres senderos aún no recorridos, quizás un poco más sinuosos, pero infinitamente más fructíferos; una suerte de filósofo, de visionario, de reformador del universo. Esta creencia tiene también raíces profundamente cratilianas:

Con tono sarcástico me había pedido que lo llamara «querido maestro» y lo mismo hacía él conmigo, pero, en realidad, por estar aún próximos a la edad en la que creemos crear lo que nombramos, ese juego nos daba cierto placer. (Proust, 2007, p. 99).

C'est sur un ton sarcastique qu'il m'avait demandé de l'appeler "cher maître" et qu'il m'appelait lui-même ainsi. Mais en réalité nous prenions un certain plaisir à ce jeu, étant encore rapprochés de l'âge où on croit qu'on crée ce qu'on nomme. (Proust, 1987-1989, I, SW, p. 89).

Seferis se interesa muy pronto por esta concepción casi mistagógica. Escribe en su ensayo Monólogo sobre la poesía: "El fin último del poeta no es el de describir las cosas, sino el de crearlas nombrándolas; creo que ese es también su gran placer" (Seferis, 1992a, p. 139). Esta convicción aparece de nuevo casi idéntica en Seis noches en la Acrópolis: "Siempre tuve la impresión de que basta nombrar una cosa para que exista" (Seferis, 2013, p. 21). Las dos nociones son extrañamente similares a la concepción del creador de nombres del Crátilo, que intentaba imitar la esencia de las cosas utilizando las letras y las sílabas, pero también a la de Plotino, uno de los filósofos neoplatónicos y sucesores de la doctrina de Platón, que relaciona pensamiento, palabra creativa y creación acordando al cratilismo un poder innovador y desde un comienzo teúrgico: "Mas la noción [el lenguaje, N. del T.], desplegando el inteligible [el pensamiento, N. del T.] y trasladándolo de la facultad intelectiva a la imaginativa, lo hace patente como en un espejo. Y en esa percepción del inteligible así reflejado y en su persistencia consiste también la memoria" (Plotino, 1985, p. 369). La elección de la palabra espejo es de un significado liminar también para Proust: la utiliza en muchas oportunidades 
para subrayar la identidad, el apego a un valor importante o la existencia de una suerte de médium metafísico que reúne dos entidades diferentes. Antes que nada, llama la atención sobre el valor de la obra literaria, en cuanto espejo de la verdad:

Un día en que encontré en un libro de Bergotte una línea a propósito de una vieja sirvienta, una broma que el magnífico y solemne lenguaje del escritor volvía aún más irónica, pero que era la misma que yo había hecho con frecuencia a mi abuela hablando de Françoise, otra vez en que - como vi- no consideraba indigno mencionar, en uno de aquellos espejos de la verdad [cursiva agregada] que eran sus obras, una observación análoga a la que yo había tenido oportunidad de formular sobre nuestro amigo el Sr. Legrandin ... me pareció de repente que mi humilde vida y los reinos de lo verdadero no estaban tan separados como había creído, que coincidían incluso sobre algunos puntos, y de confianza y de gozo lloré sobre las páginas del escritor como en los brazos de un padre recuperado. (Proust, 2007, pp. 105-106).

Un jour, ayant rencontré dans un livre de Bergotte, à propos d'une vieille servante, une plaisanterie que le magnifique et solennel langage de l'écrivain rendait encore plus ironique mais qui était la même que j'avais souvent faite à ma grand-mère en parlant de Françoise, une autre fois où je vis qu'il ne jugeait pas indigne de figurer dans un de ces miroirs de la vérité qu'étaient ses ouvrages une remarque analogue à celle que j'avais eu l'occasion de faire sur notre ami M. Legrandin ... il me sembla soudain que mon humble vie et les royaumes du vrai n'étaient pas aussi séparés que j'avais cru, qu'ils coïncidaient même sur certains points, et de confiance et de joie je pleurai sur les pages de l'écrivain comme dans les bras d'un père retrouvé. (Proust, 19871989, I, SW, p. 95).

Cabe señalar que esta cualidad intrínseca de la obra no tiene tanto que ver con el contenido verídico y ortodoxo del libro de Bergotte, sino que se trata, en realidad, de una cualidad filosófica, incluso mística de la obra, en la que se encuentra un germen que podría desarrollarse plenamente en todo corazón sensible. Proust pensaba que "un gran escritor no debe inventar, en el sentido corriente, ese libro esencial ... puesto que ya existe en cada uno de nosotros, sino traducirlo. El deber y la tarea de un escritor son los de un traductor" (Proust, 2010, p. 215) ${ }^{2}$; “un grand écrivain n'a pas, dans le sens courant, à ... inventer [un livre] puisqu'il existe déjà en chacun de nous, mais à le traduire. Le devoir et la tâche d'un écrivain sont ceux d'un traducteur" (Proust, 1987-1989, IV, TR, p. 469). El libro es visto, en consecuencia, como un espejo de nosotros mismos: sirve como un medio que nos recuerda verdades ya existentes en nosotros; es el reconocimiento de una especie de código espermático según el cual toda gran obra se escribiría con el fin de alcanzar a los corazones fértiles. El autor de una obra tal, dando a luz bajo la influencia de un imitatio dei, es responsable de la cualidad trascendente, e incluso de la claridad reluciente de su retoño: debe no solo ser un traductor de los misterios más reprimidos del alma humana; es necesario que sea también un creador adecuado de nombres, que vele con una devoción casi religiosa porque cada nombre, propio o no, esté unido a su significación natural, incluso esotérica y, necesariamente, cratiliana: "Cuando un escritor inventa un nombre propio está sometido a las mismas reglas de motivación que el legislador platónico cuando quiere crear un nombre 
común; de alguna manera debe copiar la cosa y, como tal tarea es imposible, al menos debe copiar la manera en que la lengua ha creado algunos de sus nombres" (Barthes, 2003, p. 124). El escritor es también un creador de nombres porque, por un lado, busca la pureza más grande del pensamiento, velando por la compatibilidad más eficaz posible entre significado y significante; por el otro, es asimismo un creador determinista que vela por la rectitud del significado. No solo la obra - las palabras que la componen - debe convertirse en un espejo, sino también el creador: esta es la huella más reveladora del genio literario:

Quienes producen obras geniales no son quienes viven en el medio más delicado, quienes tienen la conversación más brillante, la cultura más extensa, sino quienes han tenido la capacidad de volver - dejando bruscamente de vivir para sí mismos- su personalidad semejante a un espejo, de tal forma que su vida -por mediocre, por lo demás, que fuera, mundana e incluso, en ciertos casos, intelectualmente hablando- se refleje en ella, pues el genio consiste en la capacidad reflectante y no en la calidad intrínseca del espectáculo reflejado. (Proust, 2008a, p. 135).

Ceux qui produisent des œuvres géniales ne sont pas ceux qui vivent dans le milieu le plus délicat, qui ont la conversation la plus brillante, la culture la plus étendue, mais ceux qui ont eu le pouvoir, cessant brusquement de vivre pour eux-mêmes, de rendre leur personnalité pareille à un miroir, de telle sorte que leur vie si médiocre d'ailleurs qu'elle pouvait être mondainement et même, dans un certain sens, intellectuellement parlant, s'y reflète, le génie consistant dans le pouvoir réfléchissant et non dans la qualité intrinsèque du spectacle reflété. (Proust, 1987-1989, I, JFF, p. 545).

De la misma manera, para Seferis la relación entre poeta y obra debe ser la de un demiurgo con su creación: "En ningún lado se aplica mejor la fórmula: En el principio era el verbo, que en la poesía" (Seferis, 1992a, p. 189). El poeta se halla, antes de la era de la creación, obligado a utilizar la lengua de todos para expresar su alegría, su dolor, su amor. No obstante, sabe que esta lengua no es la que él debe utilizar, no es su propia lengua, no es la que será materializada en su propia poesía. El viaje hacia la conquista de la poesía íntima pasa necesariamente por algunas etapas: en un principio, es la búsqueda del lenguaje ideal y, enseguida, la imitación de los otros. Un poco antes del descubrimiento, sin embargo, el poeta debe permanecer completamente mudo:

Siente que debe sufrir la prueba del silencio total para descubrir en lo más profundo de sí lo que él es verdaderamente. Todo poeta auténtico pasa, creo, por tales crisis; es por eso que se dice que todo poema que uno escribe es el último. Una vez que el poeta asimila las cosas que su idiosincrasia recogió del mundo a su alrededor, llega el momento en que sentirá el vacío en su interior, en que sentirá que está en la selva oscura, como lo decía antes, en la "selva oscura", 3 solo y sin ayuda -que tenga confianza en ese vacío, bajo pena de muerte-. Es su momento más difícil, esta lucha con el objetivo de encontrar esa voz que se identifica y se incorpora a las cosas que quiere crear o, si se quiere, que crea las cosas nombrándolas. El punto extremo al que tiende el 
poeta es el de poder decir "que se haga la luz" y que la luz se haga. (Seferis, 1992b, p. 164).

Seferis pone en evidencia tres factores clave en este pasaje: por un lado, la preponderancia de la preparación poética, de ese bagaje de la experiencia del poeta, que forma el campo fecundo en el que la poesía va a desarrollarse: esto se identifica aquí con la búsqueda de la expresión poética sui generis. A continuación, es el punto crítico del silencio absoluto, el período de la fermentación que exige la reclusión y la errancia del poeta en las profundidades de su ser. La comparación con la selva oscura de Dante es muy elocuente: "En medio del camino de nuestra vida me encontré por una selva oscura, pues era extraviada la vía derecha" (Dante, 1985, p. 25). Para Dante, esta selva oscura representaría los vicios y los errores, la perdición moral e intelectual. Pero para Seferis es también un período de hallazgos, un período de contemplación esotérica durante el cual el germen de la poesía, que ya está plantado, va a echar raíces y a nacer. La página en blanco representa para él el espejo de su yo profundo, que lo ayudará a escribir:

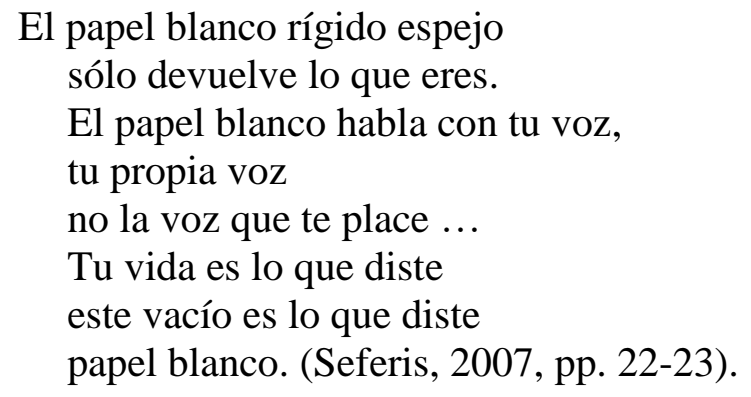

Es la etapa espermática del creador justo antes de la tercera etapa, la cosmogonía del Fiat lux que marcará la época de la recreación del mundo, la época en la que el poeta o el autor como demiurgos - volverán a formar y a reinventar el cosmos. Es la época en la que el autor procede a una suerte de mayéutica que tiene como objetivo dar a luz en la belleza artística como única contramedida para paliar las abyecciones de la selva oscura y del mundo bosquejado en Sodome et Gomorrhe. La salvación a través del arte: es ese el mensaje central tanto de Seferis como de Proust. Y no se trata, evidentemente, de una doctrina filosófica, sino de una reacción humana contra una sociedad tan desnaturalizada como resulta ser la de la Recherche, o incluso el universo de exilio y de desarraigo de Seferis. Esta tesis, si se pudiera aventurar la existencia de una tesis, se concentraría en el cambio de perspectiva: en vez de centrarse en el hombre, sus alegrías y sus miserias, se hace converger toda nuestra atención hacia su invención artística como único componente por completo benigno de un hombre trágicamente inclinado al vicio. Hablamos de mayéutica porque el sujeto debe realmente dar a luz, a través de sufrimientos y dolores espirituales, una verdad revolucionaria que cambiaría su vida de principio a fin. Quienes pueden dar a luz son los espíritus fecundos: "la fecundidad es lo que de eterno e imperecedero puede comportar un ser mortal" (Agacinski, 2005, p. 26). El espíritu fecundo "se distingue del deseo pasajero de posesión" (Agacinski, 2005, p. 26) puramente físico y deviene un espíritu de fecundidad enteramente ascético, dado que sus retoños no son materiales: el artista, mudo como lo quiere Seferis, se convierte en un verdadero asceta, en un solitario y un penitente. Es quien puede con más facilidad emprender este tipo de fecundación: tiene un poder espermático, característico de todo pionero en el dominio de la literatura: "What is the best in literature is the affirming, prophesying, 
spermatic words of men - making poets" (Emerson, 1960, p. 271), o en cualquier dominio en que la obra de un hombre pueda revolucionar gracias a una idea, una nueva perspectiva, un giro hacia una dirección innovadora para concebir una tendencia, un movimiento o una escuela de vanguardia. Esta disposición espermática se identifica a una especie de partícula

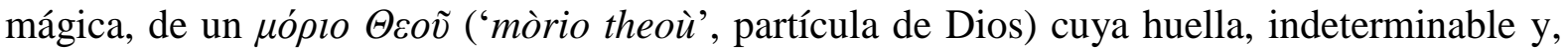
sin embargo, precisa, puede detectarse en toda obra:

En aquella cualidad desconocida de un mundo único y que ningún otro músico nos había permitido ver jamás radicaba tal vez - decía yo a Albertine - la prueba más auténtica del genio, mucho más que en el contenido de la obra misma. «iIncluso en la literatura?», me preguntaba Albertine. «Sí, incluso en la literatura.» Y, al volver a pensar en la monotonía de las obras de Vinteuil, explicaba yo a Albertine que los grandes literatos nunca han hecho sino una sola obra $\mathrm{o}$, mejor dicho, han refractado mediante diversos medios una misma belleza que aportan al mundo. «Si no fuera tan tarde, querida», le decía yo, «te lo mostraría en todos los escritores que lees mientras yo duermo, te mostraría la misma identidad que en Vinteuil. Esas frases típicas, que empiezas a reconocer como yo, mi querida Albertine, las mismas en la sonata, en el septeto, en las otras obras, sería, por ejemplo, en Barbey d'Aurevilly, si quieres, una realidad oculta revelada por una huella material. (Proust, 2009, pp. 387-388).

Cette qualité inconnue d'un monde unique et qu'aucun autre musicien ne nous avait jamais fait voir, peut-être était-ce en cela, disais-je à Albertine, qu'est la preuve la plus authentique du génie, bien plus que le contenu de l'œuvre ellemême. "Même en littérature? me demandait Albertine. - Même en littérature." Et repensant à la monotonie des œuvres de Vinteuil, j'expliquais à Albertine que les grands littérateurs n'ont jamais fait qu'une seule œuvre, ou plutôt réfracté à travers des milieux divers une même beauté qu'ils apportent au monde. "S'il n'était pas si tard, ma petite, lui disais-je, je vous montrerais cela chez tous les écrivains que vous lisez pendant que je dors, je vous montrerais la même identité que chez Vinteuil. Ces phrases-types, que vous commencez à reconnaître comme moi, ma petite Albertine, les mêmes dans la sonate, dans le septuor, dans les autres œuvres, ce serait par exemple, si vous voulez, chez Barbey d'Aurevilly une réalité cachée révélée par une trace matérielle. (Proust, 1987-1989, III, PR, pp. 877-878).

De esta forma, la virilidad espermática podría tener una cualidad esencialmente femenina de alumbramiento, cualidad que vuelva al espíritu del creador capaz de autofecundación. Uno de los rasgos más sorprendentes de la simiente en general es que, una vez fecundada, debe morir antes de renacer: "Lo que tú siembras no se vivifica, si no muere antes" (Corintios 15:36). O, según Proust, "Pues, si la semilla de trigo no muere después de que se la haya sembrado, permanecerá sola, pero, si muere, dará mucho fruto" (2010, p. 377); "car si le grain de froment ne meurt après qu'on l'a semé, il restera seul, mais s'il meurt, il portera beaucoup de fruits" (Proust, 1987-1989, IV, TR, p. 621). Así, la muerte toma de nuevo el primer papel en todo procedimiento de génesis: todo debe morir para producir vida. Solo la simiente espiritual no está destinada a tal fin: ella resiste a la muerte, la vence, porque es 
inmortal: "es la simiente del cuerpo espiritual, presente en el alma, lo que reconstituirá finalmente un cuerpo glorioso, idéntico al creado por Dios" (Agacinski, 2005, p. 287). De esta manera, lo que proviene de esta simiente inmortal es necesariamente inmortal. Proust se dio cuenta de que "la ecuación: 'ir hacia la muerte=ir hacia el nacimiento' significa: 'el nacimiento (del libro)=la muerte (del autor)=el nacimiento del escritor en el libro'. No olvidemos que se trata de darse a luz en el lenguaje" (Doubrovsky, 1974, p. 110). El autor debe sacrificar su yo, debe perder todo atributo humano para poder renacer nuevo, inmortal, a través de su obra. Su alumbramiento tiene lugar entre los dolores y los gritos de sus palabras: estas palabras son los testigos más fieles de su renacimiento de acuerdo con el arte. Ahora el artista, "en y por su libro, se dará a sí mismo identidad y eternidad, o al menos una longevidad más grande que la de la carne" (Doubrovsky, 1974, p. 111). En y por su libro, se hará inmortal.

Seferis alcanza esta etapa de fecundidad y de salvación haciendo escala en su propio infierno dantesco: esto es lo que suele llamarse, con elocuencia, la nekyia de Seferis. La

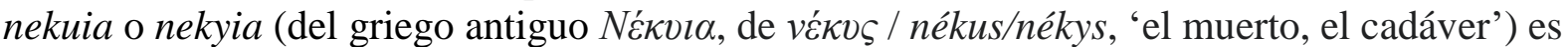
un ritual sacrificial estrechamente ligado a la mitología griega que tiene como objetivo invocar a los muertos en el curso de una necromancia. Este es también el título dado al canto XI de la Odisea, que relata la invocación del difunto adivino Tiresias por Ulises, quien busca desesperadamente un consejo sobre el futuro de su periplo. No hay que confundir la nekyia con una catábasis: esta última designa el descenso a los infiernos de dioses y de héroes como Orfeo, por ejemplo.

La Odisea es omnipresente en la obra de Seferis. En Seis noches en la Acrópolis, hay al menos cinco alusiones evidentes, mientras que en la mayoría de los poemas hay o bien un personaje o bien una escena de la epopeya de Homero puestos en primer plano. Seferis parece haber perdido su consciencia individual por haberse dedicado a la consciencia racial colectiva, tanto histórica como mitológica: se identifica con Ulises en cuanto poeta, pero también en cuanto personaje, porque "era un hombre desarraigado que había experimentado la sensación de perder sus raíces. Aspirando, a causa de una economía de la vida, a crear nuevos fundamentos, subió a toda la escala de la desesperación" (Argyriou, 1990, p. 25). Su poesía resulta ser una odisea que ocurre en el presente, pero en otro plan metafísico, que es la esencia misma del presente y que contiene un pasado muy grande y glorioso. Los versos de Seferis divagan en este paisaje lírico impregnado de nostalgia y habitado por muertos ilustres:

ya que fuimos atados y fuimos dispersados

y ya que hemos luchado con asperezas por lo que se decía inexistente, perdidos, y encontrando de nuevo un camino lleno de batallones ciegos hundiéndonos en los pantanos y en el lago de Maraton, podremos morir normalmente? (Seferis, 1968, pp. 48-49).

Ulises es el símbolo del hombre que busca su Ítaca y está, por ello, infinitamente atormentado. Para él, la nekyia representa el único modo de salvación. Pero, para comprender mejor el significado de la nekyia en la Odisea, hay que estudiar primero el papel de la muerte en la Grecia Antigua: es un papel eminente y fundamental en la educación y la civilización helénica, y dice mucho sobre las elecciones poéticas de Seferis.

Los griegos antiguos afrontaron la muerte como concepto y como fenómeno de la vida humana de manera ambigua: intentaban equilibrar y - en la medida de lo posibleneutralizar - o hasta exorcizar - el miedo que les inspiraba con la valentía y el coraje que un acto heroico suscita en el alma humana: "[h] eroism is a means of defying the time limit given 
to humans, overcoming it before its time, and winning a sort of immortality, at least in the collective memory" (Mirto, 2012, p. 127). Un acto heroico era para el griego antiguo no solo un acto de guerra extraordinario, como la hazaña formidable de los trescientos de Leónidas en Termópilas, sino también un acto moral considerable, como el de Antígona cuando desafía a su tío Creonte - padre de su prometido y jefe del estado tebano-, quien rechaza sepultar a su hermano acusándolo de traidor. El hecho representa, como veremos, una injuria inigualable para el muerto, pero también un crimen moral abominable por parte de Creonte. Antígona, desgarrada entre su amor por Hemón y el deber hacia su hermano, obedece a la ley moral y no a los decretos de Creonte, ya que "no fue Zeus el que los ha mandado publicar, ni la Justicia que vive con los dioses de abajo la que fijó tales leyes para los hombres" (Sófocles, 2000, p. 93). Finalmente, pierde su vida. Por más que las dos proezas sean completamente diferentes, ambas gozan por igual de honor y de reconocimiento colectivo: representan la definición de bella muerte: "Aquellos que hayan pagado con la vida su desprecio al deshonor en el combate, a la vergonzosa cobardía, tienen de seguro garantizado un renombre" (Vernant, 2001, p. 46). Así, la muerte como fin ineluctable se desafía y se sufre al mismo tiempo como una prueba de inmortalidad: el muerto obtiene, según J.-P. Vernant, renombre y continuidad en la memoria de los hombres de todos los tiempos (inmortalidad temporal), mientras que su cuerpo es enterrado con los más grandes honores y su tumba es venerada por siempre (inmortalidad espacial). En consecuencia, la idealización de la muerte es "una solución a la condición humana: encontrar en la muerte el modo de sobrepasar esta condición humana, vencer a la muerte por la muerte misma dotándola de un sentido que no posee, del que carece por completo" (Vernant, 2007, p. 2266).

Considerando al sujeto desde un punto de vista tanto mitológico como lingüístico, es interesante subrayar que la palabra thanatos (muerte) es en griego masculina, mientras que sus múltiples representaciones resultan ser todas femeninas. Según J.-P. Vernant:

[Es] el rostro monstruoso de Gorgona, cuya mirada, insostenible, transforma en piedra. Y es también una entidad femenina, la Ker — negra, sombría, malvada, horrible, execrable - la que representa la muerte como fuerza maléfica, ensañándose con los hombres para destruirlos, sedienta de su sangre, devorándolos para engullirlos en la noche en que el destino quiere que se pierdan. (2007, p. 1397).

Por otra parte, Thanatos es, además, un personaje mítico, la personificación de la muerte. En consecuencia, la muerte como condición estática es de género masculino, mientras todo lo que la provoca, en cuanto factor dinámico, es de género femenino. La unión armoniosa de estos dos contrarios constituye, desde entonces, el punto de partida de la creación del concepto escatológico. Por lo demás, la partenogénesis de la terrible Noche podría traducir un simbolismo patente: el griego antiguo intenta deificar sus angustias más profundas y más incomprensibles antes de vencerlas. Se trata de lo que Clémence Ramnoux llama discurso sacro: "Se busca con la palabra la cosa que le falta a los signos del mundo. La misma palabra oculta el sentido que designa" (1986, p. 200). Así, "vaciados de la imaginería con el permanente uso, los nombres toman la figura enigmática de signos: apuntando hacia alguna Cosa, sin descubrir, Inaccesible" (Ramnoux, 1986, p. 180).

Tomando prestado el uso lingüístico heracliteano que une en una misma palabra los dos contrarios que representa (Dios es día y noche...), podría pretenderse que la mentalidad precristiana se esfuerza desde su nacimiento por neutralizar, en una misma palabra o concepto angustiante, todos los miedos y las aprehensiones debidas a sentimientos y 
fenómenos que no puede explicar. De la ansiedad provocada por la ausencia de luz, va a nacer toda una serie de emociones inquietantes que serán divinizadas antes de ser combatidas y conquistadas por el advenimiento del pensamiento filosófico y la creencia del hombre clásico en sus propios poderes y potencialidades. Es el héroe clásico quien vencerá la muerte y conjurará el misterio del Más Allá.

Esta idealización de la muerte, pero también el esfuerzo por desmistificarla, condujeron al griego antiguo a hacer de ella parte integrante de su vida cotidiana: hay ritos especiales y conmemoraciones de los muertos, mientras que la comunicación con o la consulta de los muertos, la nekyia, representa una suerte de puente entre el mundo de los vivos y el Más Allá, no solo en la vida real, sino también en muchas obras literarias de la Antigüedad. La nekyia más famosa es, sin dudas, la de la Odisea: en la Antigüedad, una de las razones primordiales de la celebridad de Ulises reposaba justamente en esta aventura extraordinaria, que está representada en múltiples pinturas de la Grecia antigua, especialmente las de la Lesche, edificio público cerca de Delfos.

A decir verdad, en la Odisea se encuentran dos nekyias, la del canto XI, que representa una nekyia y una catábasis - lo que convierte a este relato en un verdadero punto de referencia para la filología que se ocupa del sujeto- y la del canto XXIV, que suele criticarse virulentamente como una nekyia de forma y contenido incompatibles con el resto de la epopeya. En el canto XI, Ulises debe partir desde la morada de Circe con rumbo al reino de Perséfone para pedir el consejo de Tiresias. El viaje, bendecido y facilitado por la terrible Circe, dura apenas un día hasta el país de los cimerios, supuesto sitio del infierno en la Antigüedad:

Allí está la ciudad y el país de los hombres cimerios, siempre envueltos en nubes y en bruma, que el Sol fulgurante desde arriba jamás con sus rayos los mira ni cuando encamina sus pasos al cielo cuajado de estrellas ni al volver nuevamente a la tierra del cielo: tan solo una noche inmortal sobre aquellos cuitados se cierne. (Homero, 2006, p. 170).

Los versos que ponen en valor la extranjería de un lugar inabordable por los rayos del Sol (con mayúscula, para resaltar el carácter del reino del sol, en contraposición con el reino de las sombras) resultan ser la única prueba que el héroe debe sortear para alcanzar el mundo de los muertos, sin duda porque Ulises hace un periplo ventajoso bajo la protección de Atenea y de otras divinidades que encontró durante sus peregrinaciones. La sangre de los animales sacrificados atrae las sombras de los muertos y del gran adivino, y Ulises los interroga sobre su futuro (nekyia o necromancia). Es un rito especial que pretende "asegurar a los difuntos, gracias a las ofrendas, una vida precaria. La sangre vertida en la fosa y de la que beberán algunas Sombras debe reanimarlas, pues según la concepción antigua es el sitio de la vida" (Dumortier, 1954, pp. 33-34). A continuación, nuestro héroe encuentra las almas de grandes personajes mitológicos de la Grecia antigua: Tiro, Antíope, Alcmena, Mégara, Leda; héroes eminentes: Equeneo, Alcínoo, Agamenón y el más famoso de todos, Aquiles; por último, se convierte en testigo del suplicio de los más grandes condenados, como Ayax, Orión, Ticio, Tántalo, Sísifo y Heracles (catábasis).

Podríamos fácilmente enfatizar el valor polisémico de la nekyia/catábasis: primero, sirve de prueba iniciática, tanto didáctica como paradigmática, en el curso del largo aprendizaje del héroe - debe pasar por el infierno antes de alcanzar su paraíso-. La nekyia responde 
también a sus inquietudes sobre el futuro, pero antes que nada hay que descifrar el significado sibilino (así, sirve, además, de prueba de sabiduría), mientras que la catábasis le sirve de ejemplo liminar —estudia las diferentes formas de muerte, pero enseña también la importancia de la vida.

El Más Allá es un mundo tan real como el de los vivos: recorriéndolo, Ulises enriquece sus experiencias, pero comprende, además, que la vida puede ser tan terrorífica como la muerte, aunque mucho más dulce que la morada de Hades. Esta muerte iniciática representa una prueba privilegiada para el héroe de la epopeya: los ojos del iniciado, sumergidos en el más allá y purgados, pueden tener ahora una perspectiva macrocósmica del mundo, lejos de las coerciones físicas de los vivos. Las mismas leyes rigen los dos mundos, pero el significado de todo acto cambia enteramente si se conocen sus repercusiones por adelantado. El hombre se convierte así en superhombre, una vez que adquiere cualidades metafísicas.

El Ulises de la mitología de Seferis retiene todos los atributos de su prototipo. Traduce la necesidad del poeta de comunicarse con los maestros, con los viejos sabios, con todos aquellos que vivieron en tiempos lejanos, para pedirles ayuda: "Recordamos los antiguos maestros que nos dejaron huérfanos" (Seferis, 1994, p. 172). Aquellos que aún están vivos no pueden, a causa de su degradación, prestar asistencia, apoyarlo. Estamos en plena guerra mundial, y Seferis debe hacer frente a circunstancias nefastas que lo conducen ineluctablemente a una confusión emocional desmesurada. El clima de envilecimiento político y social repercute en los versos escritos en esta época, en particular en los poemas "Boulevard Syngrou", "Santorin" y "Micenas". A partir de ahora, la historia trágica de Grecia irrumpirá en todos sus poemas, haciendo del verso "Dondequiera que vaya, Grecia me duele" (Seferis, 1994, p. 99) el más representativo y emblemático de toda su obra. Es en los poemas de estos períodos trágicos que experimenta la necesidad imperiosa de pedir ayuda: para él, la nekyia, la Odisea, el pasado glorioso de la Antigua Grecia, representan una solución, sin duda la única. Escribe en 1942, en plena Segunda Guerra Mundial:

"Es pesado y difícil; los vivos no me bastan

primero porque no hablan, y luego

porque tengo que interrogar a los muertos

para poder avanzar más lejos ...

Es necesario que los muertos me aconsejen" (Seferis, 1994, p. 196).

El poeta —o, más bien, su yo poético, Stratis Thalassinos- busca desesperadamente una vía de escape a un ambiente beligerante, en el que se ha perdido toda huella de humanidad y de razón. Para hacer contacto con el Más Allá, le hace falta, sin embargo, algo especial, una suerte de flor que es emblemática en el país de los muertos, el asfódelo.

"No hay asfódelos, ni violetas ni jacintos.

¿Cómo hablar con los muertos?

Los muertos solo conocen el lenguaje de las flores" (Seferis, 1994, p. 196).

El asfódelo es la flor más frecuentemente asociada con el Más Allá: "El asfódelo, la planta bulbosa de flores pálidas, puede evocar muchas asociaciones; ya en la antigüedad se discutía si debería leerse o entenderse más bien como «pradera espantosa»o «pradera cubierta de cenizas»" (Burkert, 2007, p. 266). Los campos de Asfódelos (o Prados Asfódelos) en la mitología griega son el lugar en el que permanece la mayor parte de los fantasmas de los muertos, que llevan allí una existencia insustancial y sin objeto. Son las almas que no cometieron ni crimen ni acción virtuosa las que erran eternamente sin objetivo y esperan $a d$ 
vitam aeternam. Es aquí, además, donde se encuentra el palacio de los dos soberanos de los infiernos, Hades y Perséfone. En la Odisea, se trata de un prado: “

Del océano a las ondas llegaron, al cabo de Leucas, / a las puertas del sol, al país de los sueños, y pronto / descendiendo vinieron al prado de asfódelos, donde / se guarecen las almas, imágenes de hombres exhaustos. (Homero, 2006, p. 384).

El poema de Seferis acaba con una nota de desesperanza, con un grito que pretende penetrar las tinieblas del Hades por su desgarro: ¡Ayúdennos!

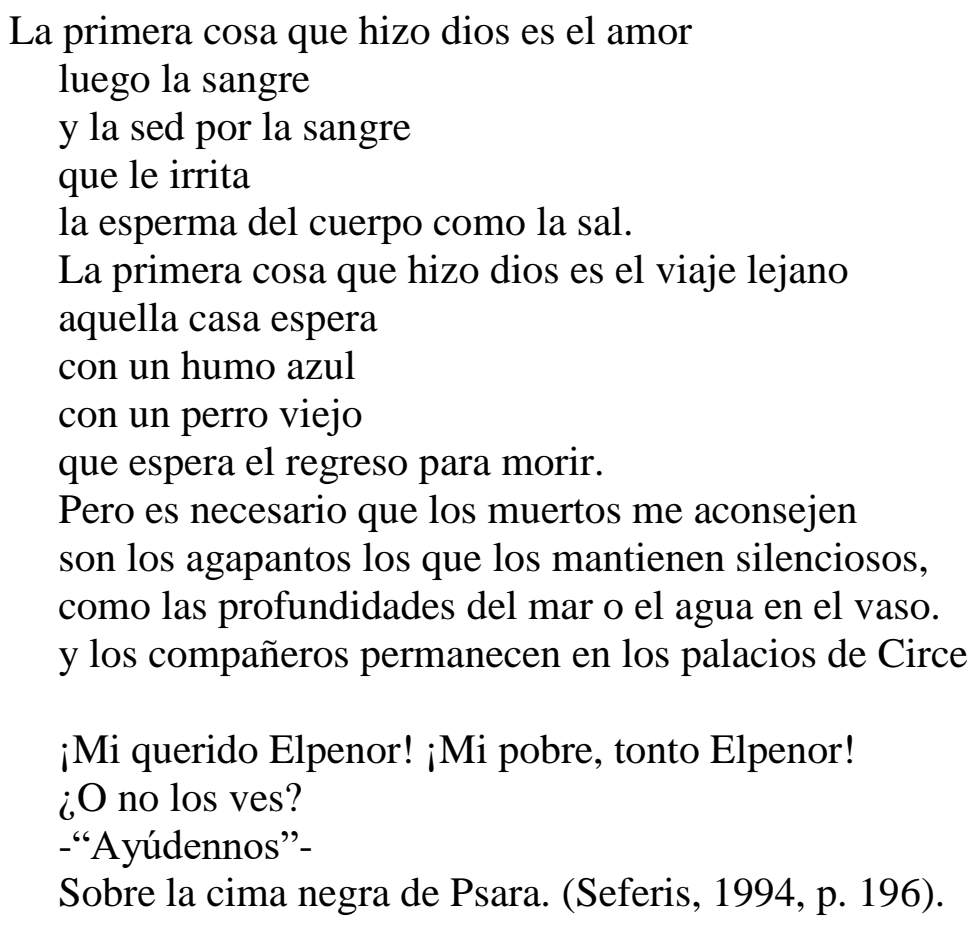

Se constatan en estos versos rasgos sui generis de la poesía de Seferis que son tomados de la Odisea: la sangre que es indispensable para la nekyia; el amor, la casa y el perro que esperan a Ulises; los agapantos — sustitutos de los asfódelos-; Circe y Elpenor, los personajes homéricos. Todos estos elementos, y los personajes, antes que nada, juegan un rol privilegiado:

Solo la evocación de sus nombres sirve de insignia que asegura un lugar común de armonía: funcionan entre el escritor y el lector como mito, con la definición particular que Seferis atribuye al mito. La población humana de Mythistorima resulta estar lejos de los perjuicios cronológicos: el poeta es indiferente al hecho de que los personajes que aparecen uno al lado del otro sean antiguos o modernos. Esta indiferencia cronológica se debe a un mecanismo espontáneo de la memoria, que pasa de algo antiguo a algo moderno sin ninguna preocupación de homogeneidad crónica. También se 
debe a la mitificación, a un procedimiento que transforma la historia en mito y que tiene como punto de partida la "emoción histórica", esa emoción que considera historia todo lo que está vivo y que hace coexistir al mismo tiempo personajes que han vivido en tiempos diferentes. (Vitti, 1994, pp. 78-79).

Esta noción de emoción histórica es una de las características más sobresalientes de T. S. Eliot y se elabora minuciosamente en "Introducción a T. S. Eliot" (Seferis, 1992a, pp. 17-47). Podría decirse incluso que la mitificación seferiana, fundada principalmente sobre la nekyia, representa el dispositivo respectivo de las intermitencias proustianas, en la medida en que sirve de elemento de unificación cronológica en relación con el conjunto de la obra del poeta. Aunque este mecanismo sea muy exitoso en lo que respecta a los poemas, resulta ser bastante problemático en la novela, sin duda porque esta constituye su primer esbozo.

Ahora bien, en Seis noches en la Acrópolis, la comunicación con el pasado acaba siendo igualmente imperativa. Por esto, los jóvenes eligieron la Acrópolis como lugar privilegiado para comunicarse con su pasado ilustre bajo una luna llena, que es, además, el momento indicado para una necromancia:

Estos bloques de mármol jugarán para los rayos lunares el mismo papel que los espejos de Arquímedes jugaron para los rayos solares: los obligarán a encontrarse con ustedes, oh ríos aprisionados, con la mayor intensidad posible ... En la Acrópolis, bajo la luna llena, encontraremos la energía necesaria para que nuestras aguas puedan comunicarse entre ellas. Quizás también encontraremos allí otra fuerza que nos ayude a alcanzar nuestro objetivo, la fuerza del legado de nuestros ancestros inmortales... El mundo no puede hablar si no lo alimentas con tu sangre. (Seferis, 2013, p. 42).

Algunas páginas más tarde, Seferis anuncia su plan latente:

A lo lejos, en el fondo, los mármoles de la Acrópolis resplandecían como grandes piedras blancas. Stratis se esforzaba por conciliar el tiempo presente, que fluía con el ritmo lánguido de las salmodias y venía a fundirse por encima de las pequeñas llamas, con este otro tiempo que parecía contemplarlo, inmóvil, desde lo alto de la ciudadela, a través de las pupilas cerradas de los mármoles como desde el fondo de un mar tranquilo. (2013, p. 75).

La presencia de la Acrópolis, sin embargo, en lugar de facilitar el vínculo con el pasado, lo vuelve problemático: "este pasado es omnipresente, abrumador, tan pesado que los seres se quedan paralizados, como el paisaje urbano ateniense ante la colina de la Acrópolis" (Brumes, 2014, p. 3). Los personajes no pueden alcanzar la salvación porque, además de las ruinas visuales, hay también ruinas literarias, un número muy grande de citas: "En todo momento aparecen, en el tejido mismo de la trama narrativa, los signos del pasado voluminoso que, sin embargo, hay que metamorfosear en presente" (Brumes, 2014, p. 3). Efectivamente, hay setenta y cinco citas en doscientas cuarenta y dos páginas, citas de poetas y de escritores diferentes, de extensión y de pertinencia variables. Seferis, sin duda, está muy influenciado por el descubrimiento relativamente reciente de La tierra baldía, de T. S. Eliot, 
cuyo antepenúltimo verso - "estos fragmentos he orillado contra mi ruina" (Eliot, 2001, p. 59) - parece resumir la idea central de la novela: "construir algo a partir de ruinas, a pesar de ellas y, finalmente, contra ellas" (Brumes, 2014, p. 3). Pero las ruinas de la novela dominan a los personajes, son obstinadas y remanentes:

Tenía la impresión de que la Acrópolis había permanecido intacta hasta esta tarde, y que dos milenios de tiempo comprimido acababan justamente de liberarse reduciéndola a migajas ... Después de haber pasado el Odeón, Stratis echó de nuevo un vistazo hacia el peñasco. Le pareció que tenía un aire de resistencia terca, y se asombró de que aún estuviera de pie luego de un sismo semejante. (Seferis, 2013, p. 140).

En consecuencia, la imposibilidad de la salvación a través del pasado conduce al alejamiento progresivo de la Acrópolis: "las noches son allí más cortas, los personajes experimentan más reticencias, su búsqueda debe ejercerse hacia un lugar lejano e inhallable" (Brumes, 2014, p. 3). No obstante, el fin enigmático, poético y casi taumatúrgico de la novela deja algunas esperanzas:

— ¿Nunca pensaste tomar el otro camino, Stratis? ¿El camino de arriba...?

Me pregunté qué quería decir, estaba dominado por una voluntad extranjera.

Ella estaba ahora parada al lado de la losa de mármol. Su túnica era de amianto incandescente.

- i... que las almas, a veces, abolen la muerte para volver a ser piel y labios?

Tenía allí, delante de mí, una llama semejante. Mi cerebro trataba desesperadamente de saber si yo era también parte de aquello que miraba. Experimenté un dolor vivo, que se expandió por todo mi cuerpo. Creí que me desgarraban. Luego sentí un relámpago que cortó el tiempo como una gran serpiente, de golpe. Vi un pequeño montón de cenizas de lino en el lugar donde se encontraban sus tobillos. $V i$ resucitar un ser de entre los mármoles. (Seferis, 2013, p. 242).

El tiempo podría efectivamente haber realizado el milagro, las ruinas podrían haber hecho resucitar los mármoles. Este fin que deja semillas de milagro y de esperanza sobreviene sin duda como un cambio repentino para modificar de principio a fin todo el ambiente asfixiante de la novela y para iluminar un poco la vía de la salvación para Stratis/Seferis. Esto podría ser también "la prueba para nosotros de esta voluntad deliberada en Seferis de dar, desde esta época, una profundidad mítica a su creación" (Kohler, 1985, p. 145).

En Proust, por otra parte, hay un término análogo a la nekyia griega que se utiliza de forma singular: "puesto que toda mirada habitual es una necromancia y cada rostro que amamos es el espejo del pasado" (Proust, 2005, p. 144); "puisque tout regard habituel est une nécromancie et chaque visage qu'on aime, le miroir du passé” (Proust, 1987-1989, II, CG, p. 439). Pero hay también una catábasis y no una nekyia, en la medida en que la nekyia constituye un rito que presupone un sacrificio cuya utilidad es disponer favorablemente a quien se interrogará en los infiernos sobre el futuro o sobre una cuestión precisa. Por el 
contrario, la catábasis es más bien una prueba de iniciación que el héroe antiguo debe pasar antes de alcanzar la consolidación de su calibre heroico. Este descenso a los infiernos tiene lugar durante un sueño, lo que lo vuelve mucho más plausible. La ventaja del sueño es que "la inteligencia y la voluntad, momentáneamente paralizadas, ya no podían protegerme contra la crueldad de mis impresiones verdaderas" (Proust, 2008, p. 173); "l'intelligence et la volonté momentanément paralysées ne pouvaient plus ... disputer à la cruauté de[s] impressions véritables" (Proust, 1987-1989, III, SG, p. 157), es decir, los sentimientos más escrupulosamente reprimidos por el razonamiento tienen por fin curso libre para que sean tratados por el proceso cognitivo de forma no censurada.

Una de las funciones más importantes de la inteligencia es la de mitigar la intensidad de las impresiones para hacerlas inofensivas para la sensibilidad. Es una suerte de amortiguador afectivo que absorbe toda conmoción emotiva susceptible de desregular el funcionamiento de la sensibilidad del ser. Por esta razón, la receptividad emocional del ser en el curso del sueño crece hasta el punto de que

el conocimiento interno, colocado bajo la dependencia de los trastornos de nuestros órganos, acelera el ritmo del corazón o de respiración, porque una misma dosis de espanto, tristeza, remordimiento, actúa, con una potencia centuplicada, si se la inyecta así en nuestras venas. (Proust, 2008, p. 173).

La connaissance interne, placée sous la dépendance des troubles de nos organes, accélère le rythme du cœur ou de la respiration, parce qu'une même dose d'effroi, de tristesse, de remords agit, avec une puissance centuplée si elle est ainsi injectée dans nos veines. (Proust, 1987-1989, III, SG, p. 157).

Bajo la égida del conocimiento interno, comenzamos el viaje al mundo de Morfeo, que puede llevarnos, si lo deseamos, al reino de Hades:

Para recorrer las arterias de la ciudad subterránea sobre las olas negras de nuestra propia sangre como sobre un Leteo interior de séxtuples repliegues, grandes figuras solemnes se nos aparecen, nos abordan y nos abandonan y nos dejan desechos en lágrimas. (Proust, 2008, p. 173).

Pour y parcourir les artères de la cité souterraine, nous nous sommes embarqués sur les flots noirs de notre propre sang comme sur un Léthé intérieur aux sextuples replis, de grandes figures solennelles nous apparaissent, nous abordent et nous quittent, nous laissant en larmes. (Proust, 1987-1989, III, SG, p. 157).

Deberíamos subrayar, en primer lugar, el esbozo de una escena acuática, como es el caso en la mayoría de los descensos registrados. Es interesante, sin embargo, constatar que el campo léxico no abarca solo palabras de connotación plenamente náutica - embarcado, naves, Leteo-, que remiten a un viaje marítimo convencional, sino que sugiere más bien un viaje interior por nuestras arterias y nuestra sangre: se trata más de una excursión en las 
entrañas del ser que de un viaje exterior a nuestra propia consciencia; no hay un transporte a otra dimensión, sino una introspección en la esencia de nosotros mismos. Para ello, es necesario olvidar por un momento al ser de la víspera; hay que beber el agua del Leteo para distanciarnos de nuestra inteligencia. La diligencia de la inmersión aturde; las figuras de los primeros muertos aparecen, solitarias y solemnes. El ser profundo las reconoce, aunque se trate de figuras y sean, por eso, indeterminadas e imprecisas. Sin embargo, se alcanza un primer desborde de sensibilidad expresada en lágrimas interiores, retenidas durante mucho tiempo. La idea del desplazamiento se refuerza por los verbos abordent y quittent: estamos en pleno Hades y el Narrador busca desesperadamente a su abuela: "busqué en vano la de mi abuela: sin embargo, sabía que aún existía, pero con una vida disminuida, tan pálida como la del recuerdo; aumentaba la oscuridad y el viento" (Proust, 2008, p. 173); "Je cherchai en vain celle de ma grand-mère dès que j'eus abordé sous les porches sombres; je savais pourtant qu'elle existait encore, mais d'une vie diminuée, aussi pâle que celle du souvenir; l'obscurité grandissait, et le vent" (Proust, 1987-1989, III, SG, p. 157). Su intuición o su deseo arden, le hacen creer que su abuela aún vive, pero ¿qué tipo de vida lleva? Parece, en realidad, identificarse con la imagen virtual que el Narrador tiene de ella en su memoria, una imagen ya atenuada por el olvido y el distanciamiento.

A medida que las tinieblas se opacan, el viento parece borrar las huellas de este recuerdo precioso. El Narrador requiere ayuda: "mi padre, que debía conducirme hasta ella, no llegaba" (Proust, 2008, p. 173); "mon père n'arrivait pas qui devait me conduire à elle" (Proust, 1987-1989, III, SG, p. 157). En los infiernos se necesita un guía, no es posible aventurarse en la oscuridad siniestra sin los auspicios de un protector: para los muertos, es necesario un psicopompo, un conductor de almas. Para los vivos, es necesario un andropompo, un conductor de hombres. La elección de una protección viril parece elocuente en este reino tenebroso. La falta de apoyo conmociona momentáneamente al Narrador, que se desespera y mezcla sueño y realidad:

De repente me faltó la respiración, sentí como endurecido mi corazón, acababa de recordar que llevaba muchas semanas sin escribir a mi abuela. ¿Qué iba a pensar de mí? «Dios mío», me decía, «qué desgraciada debe de sentirse en ese cuartito que hemos alquilado para ella, tan pequeño como el de una antigua sirviente, en el que se encuentra totalmente sola, con la custodia que hemos puesto para cuidarla y no puede moverse, pues sigue un poco paralizada, iy no ha querido levantarse ni una sola vez! Debe de creer que la he olvidado desde que murió, ¡qué sola y abandonada debe de sentirse! ¡Oh! Tengo que correr a verla, no puedo esperar ni un minuto, no puedo esperar a que mi padre llegue, pero, ¿dónde es? ¿cómo he podido olvidar la dirección? ¡Con tal de que me reconozca aún! ¿Cómo he podido olvidarla durante meses?» Está obscuro, no la encontraré, el viento me impide avanzar. (Proust, 2008, p. 173).

Tout d'un coup la respiration me manqua, je sentis mon cœur comme durci, je venais de me rappeler que depuis de longues semaines j'avais oublié d'écrire à ma grand-mère. Que devait-elle penser de moi ? «Mon Dieu, me disais-je, comme elle doit être malheureuse dans cette petite chambre qu'on a louée pour elle, aussi petite que pour une ancienne domestique, où elle est toute seule avec la garde qu'on a placée pour la soigner et où elle ne peut pas bouger, car elle est toujours un peu paralysée et n'a pas voulu une seule fois se lever! Elle doit croire que je l'oublie depuis qu'elle est morte, comme elle doit 
se sentir seule et abandonnée ! Oh ! il faut que je coure la voir, je ne peux pas attendre une minute, je ne peux pas attendre que mon père arrive mais où estce ? comment ai-je pu oublier l'adresse ? pourvu qu'elle me reconnaisse encore ! Comment ai-je pu l'oublier pendant des mois?» Il fait noir, je ne trouverai pas, le vent m'empêche d'avancer. (Proust, 1987-1989, III, SG, pp. 157-158).

La escena descripta se parece curiosamente a la de la habitación de la abuela justo antes de dormir, el último recuerdo que él tiene de ella. Entre los detalles realistas, se introducen de forma arbitraria pensamientos sin lógica, remordimientos de un nieto que habría debido llorar a su abuela, que habría debido hacer un duelo parecido al de su madre. Pero el padre aparece para calmarlo, agregando algunos detalles de la vida de la abuela en el Más Allá:

Pero ahí está mi padre paseándose delante de mí; le grito: «¿Dónde está la abuela? Dime la dirección. ¿Está bien? ¿Seguro que no le falta de nada?». «Claro que no», me dice mi padre, «puedes estar tranquilo. Su custodia es una persona cabal. De vez en cuando enviamos una pequeña suma para que puedan comprarle lo poco que necesita». (Proust, 2008, pp. 173-174).

Mais voici mon père qui se promène devant moi; je lui crie : "Où est grandmère ? dis-moi l'adresse. Est-elle bien ? Est-ce bien sûr qu'elle ne manque de rien ? - Mais non, me dit mon père, tu peux être tranquille. Sa garde est une personne ordonnée. On envoie de temps en temps une toute petite somme pour qu'on puisse lui acheter le peu qui lui est nécessaire. (Proust, 1987-1989, III, SG, p. 158).

La custodia cabal de la abuela es, sin dudas, Cerbero, mientras que la pequeña suma es el óbolo, esa moneda de la Grecia antigua que, según los ritos funerarios, había que dejar en la boca del muerto para pagar a Caronte el cruce del Estigia. Las almas que no podían pagar estaban condenadas a errar sobre las orillas del Estigia durante cien años. En consecuencia, para asegurar el bienestar de los muertos, había que hacer ese negocio con el déspota del mundo subterráneo.

El padre conduce ahora la conversación al tema más impresionable para el Narrador: "A veces pregunta qué ha sido de ti. Le dijimos incluso que ibas a escribir un libro. Pareció contenta" (Proust, 2008, p. 174); "Elle demande quelquefois ce que tu es devenu. On lui a même dit que tu allais faire un livre. Elle a paru contente" (Proust, 1987-1989, III, SG, p. 158). Estas cuatro frases, muy cortas para los estándares proustianos, estos cuatro golpes ensordecedores para la sensibilidad del Narrador, desencadenan un trastorno monumental: son la llave que abre el saco de Eolo con los sentimientos de nuestro héroe, porque se concentran en los dos temas más delicados: el sueño de convertirse en escritor y el duelo por la muerte:

Entonces me pareció recordar que, un poco después de su muerte, mi abuela me había dicho sollozando con expresión humilde, como una vieja sirviente expulsada, como una extraña: «De todos modos, me permitirás verte alguna 
vez, no dejes pasar demasiados años sin visitarme. Piensa que has sido mi nieto y que las abuelas no olvidan». Al volver a ver el rostro tan sumiso, tan desdichado, tan dulce, que tenía, quise correr inmediatamente y decirle lo que debería haberle respondido entonces: «Pero, abuela, me verás todo lo que quieras, sólo te tengo a ti en el mundo, nunca me separaré de ti». ¡Cómo debió de hacerla sollozar mi silencio en tantos meses que no he ido allí donde está acostada! ¿Qué se habrá dicho? (Proust, 2008, p. 174).

Alors je crus me rappeler qu'un peu après sa mort, ma grand-mère m'avait dit en sanglotant d'un air humble, comme une vieille servante chassée, comme une étrangère: «Tu me permettras bien de te voir quelquefois tout de même, ne me laisse pas trop d'années sans me visiter. Songe que tu as été mon petit-fils et que les grand-mères n'oublient pas.» En revoyant le visage si soumis, si malheureux, si doux qu'elle avait, je voulais courir immédiatement et lui dire ce que j'aurais dû lui répondre alors: «Mais, grand-mère, tu me verras autant que tu voudras, je n'ai que toi au monde, je ne te quitterai plus jamais.» Comme mon silence a dû la faire sangloter depuis tant de mois que je n'ai été là où elle est couchée! Qu'a-t-elle pu se dire? (Proust, 1987-1989, III, SG, p. 158).

Desde la intermitencia iniciada con "Conmoción de toda mi persona" (Proust, 2008, p. 168); "Bouleversement de toute ma personne" (Proust, 1987-1989, III, SG, p. 152), algunas páginas antes, la memoria del Narrador se encuentra en pleno trabajo de reconstitución del pasado y de los sentimientos reprimidos. El recuerdo de una conversación después de la muerte de la abuela, sin duda en un sueño similar, lo atormenta: pone de relieve una imagen humillada, trágicamente desdeñada de la abuela. Es él quien la humilló a ese punto desdeñando y profanando su memoria. Pero, a diferencia de los nietos, las abuelas no olvidan. Y esto vuelve aún más punzante el dolor del Narrador. Su silencio sonoro, la apatía con la que recibe la pérdida del ser amado, no podrán disfrazarse más bajo la pasividad de la inteligencia. Debe actuar inmediatamente para resarcir el crimen cometido:

Y también sollozando dije a mi padre: «Rápido, rápido, su dirección, llévame». Pero él respondió: «Es que... no sé si podrás verla y, además, mira, está muy débil, muy débil, ya no es la misma, creo que te resultará más que nada duro y no recuerdo el número exacto de la avenida». «Pero dime, tú que lo sabes. No es verdad que los muertos ya no viven. No es verdad, de todos modos, pese a lo que dicen, puesto que la abuela sigue existiendo». Mi padre sonrió con tristeza: «iOh! Muy poco, verdad, muy poco. Creo que sería mejor que no fueras. No le falta de nada. Hay quien va a ordenarle todo». «Pero, ¿pasa mucho tiempo sola?». «Sí, pero es mejor para ella. Es mejor que no piense, sólo podría causarle pena. Con frecuencia causa pena pensar. Por lo demás, está, verdad, muy apagada. Te dejaré la indicación precisa para que puedas ir; no sé qué podrías hacer allí y no creo que la custodia te dejara verla». «Pero sabes perfectamente que yo viviré cerca de ella, ciervos, ciervos, Francis Jammes, tenedor». (Proust, 2008, p. 174). 
Et c'est en sanglotant que moi aussi je dis à mon père: «Vite, vite, son adresse, conduis-moi.» Mais lui: «C'est que... je ne sais si tu pourras la voir. Et puis, tu sais, elle est très faible, très faible, elle n'est plus elle-même, je crois que ce te sera plutôt pénible. Et je ne me rappelle pas le numéro exact de l'avenue». «Mais dis-moi, toi qui sais, ce n'est pas vrai que les morts ne vivent plus. Ce n'est pas vrai tout de même malgré ce qu'on dit, puisque grand-mère existe encore.» Mon père sourit tristement: «Oh! bien peu, tu sais, bien peu. Je crois que tu ferais mieux de n'y pas aller. Elle ne manque de rien. On vient tout mettre en ordre». «Mais elle est souvent seule?» «Oui, mais cela vaut mieux pour elle. Il vaut mieux qu'elle ne pense pas, cela ne pourrait que lui faire de la peine. Cela fait souvent de la peine de penser. Du reste, tu sais, elle est très éteinte. Je te laisserai l'indication précise pour que tu puisses y aller; je ne vois pas ce que tu pourrais y faire et je ne crois pas que la garde te la laisserait voir». «Tu sais bien pourtant que je vivrai toujours près d'elle, cerfs, cerfs, Francis Jammes, fourchette». (Proust, 1987-1989, III, SG, pp. 158-159).

El padre lo disuade: es el obstáculo que hay que superar para alcanzar el objetivo, para salir del Hades como un hombre nuevo. Le describe el estado actual de la abuela: el "elle n'est plus elle-même" oculta una verdad sibilina: la existencia presente de la abuela tiene poco que ver con su existencia terrenal. Lo que importa para ella ahora es no pensar, porque cogito ergo patior ('pienso, luego sufro'). Sufrió tanto que sería mejor dejarla en esos limbos del pensamiento y del olvido para que por fin encontrara reposo.

El Narrador debe comprender que no puede hacer nada por la abuela; sin embargo, no se trataba del todo de su bienestar, sino de un ajuste de cuentas del Narrador consigo mismo: para que él también encontrara reposo, fue necesario descender a lo más profundo de sí mismo, y, una vez allí, debió ser tranquilizado por una voz de autoridad que decía que era inútil demorarse en senderos que no conducen a ningún sitio. No lo tiene que perdonar la abuela, se tiene que perdonar él mismo. La catábasis/sueño acaba con estas palabras enigmáticas: "cerfs, cerfs, Francis Jammes, fourchette", de las que Liliane Fearn (1967) explicó pertinentemente el simbolismo. Aun así, más allá del simbolismo individual de cada palabra, hay sin dudas una doble utilidad global en esta selección de gracia ambigua: por un lado, parecen ser las palabras clave que ponen fin a la catábasis/sueño, de acuerdo con Gérard Genette: "la secuencia infra-linguística cerfs, Francis Jammes, fourchette no se da en absoluto como ejemplo del lenguaje onírico, sino como testimonio de ruptura y de incomprensión, al despertar, entre este lenguaje y la consciencia vigilante" (1972, p. 199); y por otro, su valor puramente acústico, incluso onomatopéyico, parece verbalizar —mediante sus fricativas y líquidas - el ruido de un ascenso brusco y precipitado hacia la vigilia, ascenso que se lleva a cabo — como el descenso — en un ambiente acuático:

Pero ya había vuelto a cruzar el río de meandros tenebrosos; había vuelto a subir a la superficie en la que se abre el mundo de los vivos; conque, si repetía otra vez «Francis Jammes, ciervos, ciervos», la continuación de esas palabras ya no me ofrecía el sentido límpido y la lógica que expresaban tan naturalmente para mí un instante antes y ya no podía recordar. (Proust, 2008, pp. 174-175). 
Mais déjà j'avais retraversé le fleuve aux ténébreux méandres, j'étais remonté à la surface où s'ouvre le monde des vivants; aussi si je répétais encore : «Francis Jammes, cerfs, cerfs», la suite de ces mots ne m'offrait plus le sens limpide et la logique qu'ils exprimaient si naturellement pour moi il y a un instant encore et que je ne pouvais plus me rappeler. (Proust, 1987-1989, III, SG, p. 159).

Después de todo, parece evidente que no se trata de un simple sueño, sino de una experiencia esotérica, de la búsqueda desesperada de un ser amado muerto, cuya ausencia provocó dolor de una manera diferida a causa del trabajo de las intermitencias. El hecho de que esta catábasis virtual se identifica, como ya lo subrayamos, con un descenso a las profundidades de nosotros mismos, hace muy pertinente la concepción junguiana de esta práctica psicoanalítica. Jung utilizó el concepto de nekyia para ilustrar el procedimiento de introversión consciente en las capas profundas de la psique inconsciente. Para él, la nekyia no es solo un descenso en el abismo de nuestro inconsciente, es una catábasis de significación mayor cuyo objetivo es la restauración completa del ser. ¿Acaso Seferis no tenía, de hecho, el mismo objetivo?

¿Podríamos, en definitiva, decir que Seis noches en la Acrópolis es una novela "muy fallida ... en la que la misma torpeza es el mejor testimonio interno de su casi total fidelidad a la versión original'? (Kohler, 1985, pp. 134-135). Roderick Beaton no está del todo de acuerdo. Él dice: "Had Seferis published, in 1930, the finished version that he completed in 1954, it would surely have claimed a distinguished place among the pioneers of Greek Modernist prose" (Beaton, 2001, p. 182). A decir verdad, podemos encontrar en la novela todos los signos precursores del genio poético de Seferis en forma embrionaria: su cratilismo, el aspecto soteriológico de la escritura estimulado por la nekyia, el papel del tiempo y, sobre todo, el dispositivo crónico de la mitificación.

Es, por cierto, muy interesante lo que Beaton pone en evidencia cuando inscribe Seis noches... en "that tradition devoted to the development of a creative artist, of which Proust's monumental Recherche is both the crowning example and the one with which Seferis was most directly in dialogue" (2001, p. 182). Yorgos Seferis estableció, sin ninguna duda, un diálogo artístico y una relación estrecha con la poética de Marcel Proust fundamentalmente porque entendía sus inquietudes y porque compartía su punto de vista sobre el arte. Durante la Navidad de 1948, escribe en sus Jours:

Leo esta narración de Ruskin: «Turner estaba un día dibujando el puerto de Plymouth y algunos navíos, a una milla o dos de distancia, vistos a contraluz. Cuando le mostró este dibujo a un oficial de marina, éste lo observó con sorpresa y objetó con una indignación muy comprensible que los navíos de línea no tenían portas. 'No, dice Turner, ciertamente no. Si usted se sube al monte Edgecumbe y mira los navíos a contraluz, bajo poniente, verá que no puede percibir las portas'. 'Bueno, dice el oficial aún indignado, pero usted sabe que hay portas'. 'Sí, dice Turner, lo sé, pero mi trabajo es dibujar lo que veo, no lo que sé’». (Seferis, 1996, pp. 128-129). 
Esta observación aparentemente anodina de Ruskin engloba, sin embargo, la quintaesencia del arte proustiano: "el esfuerzo de Elstir para no exponer las cosas tal como sabía que eran, sino según esas ilusiones ópticas de las que se compone nuestra visión primordial" (Proust, 2008a, p. 426); "l'effort d'Elstir de ne pas exposer les choses telles qu'il savait qu'elles étaient, mais selon ces illusions optiques dont notre vision première est faite" (Proust, 19871989, I, JFF, p. 194). Una pintura o un personaje de la novela son considerados habitualmente como representaciones de la realidad: remiten a un paisaje o a un ser real vistos en una perspectiva globalizante, pero a priori estática y unidimensional.

El gran pintor, así como el gran escritor, se distinguen porque hacen original esta percepción habitual de la realidad revolucionando, antes que todo, la mirada que arrojan sobre ella: los nuevos ojos instauran nuevas leyes y el universo creado - la obra artísticaimpone una perspectiva que influencia nuestra propia manera de percibir el espacio y el tiempo. Para revolucionar la forma de contemplar el mundo, el pintor original utiliza los colores y el arte de esbozar los contornos de los seres y de la naturaleza en combinaciones completamente novedosas, para materializar su concepción individual. El escritor, en cambio, debe esforzarse por cristalizar la imaginación en palabras: palabras que deben incluir en su contenido semántico una pintura iconoclasta en relación con el esbozo de la realidad tradicionalmente reflejada por ellas. Y es justamente esta nueva mirada y esta óptica iconoclasta - de un Proust, de un Seferis - lo que caracteriza a los artistas sublimes.

\section{Referencias bibliográficas}

Agacinski, S. (2005). Métaphysique des sexes: Masculin/Féminin aux sources du christianisme. París: Seuil.

Alighieri, D. (1985). La Divine Comédie: L'Enfer (Trad., introducción y notas de J. Risset). París: GF-Flammarion.

Argyriou, A. (1990). Dix-sept textes pour Séféris. Atenas: Kastaniotis.

Barthes, R. (2003). El grado cero de la escritura (Trad. de N. Rosa y P. Willson). Buenos Aires: Siglo Veintiuno.

Beaton, R. (2001). Seferis and the novel: A reading of Six Nights on the Acropolis. Byzantine and Modern Greek Studies, (25), 156-184.

Burkert, W. (2007). Religión griega. Arcaica y clásica (Trad. de H. Bernabé). Madrid: Abada.

Doubrovsky, S. (1974). La place de la madeleine, Écriture et fantasme chez Proust. París: Mercure de France.

Dumortier J. (1954). L'évocation des morts dans l'Odyssée. Bulletin de l'Association Guillaume Budé, (3), 27-40.

Eliot, T. S. (2001). La tierra baldía (Trad. de J. Malpartida Ortega). Barcelona: Círculo de Lectores.

Emerson, R. W. (1960). The Journals and Miscellaneous Notebooks of Ralph Waldo Emerson. Cambridge: Belknap Harvard UP.

Genette, G. (1972). Figures III. París: Seuil.

Homero. (2006). Odisea (Trad. de J. M. Pabón). Madrid: Gredos.

Kohler, D. (1985). L'aviron d'Ulysse: l'itinéraire poétique de Georges Séféris. París: Les Belles Lettres.

Kohler, D. (1989). Georges Séféris, qui êtes-vous? Lyon: Éditions La manufacture.

Mirto, M. S. (2012). Death in the Greek world (Trad. de A. M. Osborne). Oklahoma: University of Oklahoma Press.

Platón. (2008). Euvres complètes. París: Flammarion.

Plotino. (1985). Enéadas III-IV (Trad. de J. Ipal). Madrid: Gredos. 
Proust, M. (2005). La parte de Guermantes (Trad. de C. Manzano). Buenos Aires: Debolsillo. Proust, M. (2007). Por la parte de Swann (Trad. de C. Manzano). Buenos Aires: Debolsillo.

Proust, M. (2008a). A la sombra de las muchachas en flor (Trad. de C. Manzano). Buenos Aires: Debolsillo.

Proust, M. (2008b). Sodoma y Gomorra (Trad. de C. Manzano). Buenos Aires: Debolsillo.

Proust, M. (2009). La prisionera (Trad. de C. Manzano). Buenos Aires: Debolsillo.

Proust, M. (2010). El tiempo recobrado (Trad. de C. Manzano). Buenos Aires: Debolsillo.

Proust, M. (1987-1989). À la recherche du temps perdu (4 vol.). París: Gallimard.

Ramnoux, C. (1986). La nuit et les enfants de la nuit dans la tradition grecque. París: Flammarion.

Seferis, G. (1968). Mythistorima y otros poemas. Barcelona: Orbis.

Seferis, G. (1988). Pages de journal: 1925-1971. París: Mercure de France.

Seferis, G. (1992a). Essais I. Atenas: Ikaros.

Seferis, G. (1992b). Essais II. Atenas: Ikaros.

Seferis, G. (1994). Poèmes. Atenas: Ikaros.

Seferis, G. (1996). Jours V: janvier 1, 1945-avril 19, 1951. Atenas: Ikaros.

Seferis, G. (2007). Breve antología (Trad. de J. G. Torres). México: UNAM.

Seferis, G. (2013). Six nuits sur l'Acropole. Clermont-Ferrand: Le bruit du temps.

Sófocles. (2000). Antígona (Trad. de A. Alamillo). En Autor, Tragedias. Madrid: Gredos.

Theotokás, G. (2005). Georges Séféris comme je l'ai connu. En Autor, À la Recherche de la clarté: Essais sur la littérature nouvelle grecque et européenne. Atenas: Éstia.

Vernant, J.-P. (2001). La bella muerte y el cadáver ultrajado. En Autor, El individuo, la muerte y el amor en la Antigua Grecia (pp. 45-81). Buenos Aires: Paidós.

Vernant, J.-P. (2007). Euvres (Tomos 1 y 2). París: Seuil.

Vitti, M. (1994). Usure et logos: Introduction à la poésie de Georges Séféris. Atenas: Éstia.

\section{Notas}

\footnotetext{
${ }^{1}$ Las traducciones de la mayoría de las citas son mías. En caso contrario, coloqué la referencia de las traducciones al español que utilicé. Para las citas de Proust utilicé la traducción de En busca del tiempo perdido de Carlos Manzano e incorporé, a continuación, el original en francés (N. del T.).

${ }^{2}$ La transcripción de la traducción modifica levemente la cita elegida.

${ }^{3}$ En italiano, en el original (N. del T.).
} 